\title{
Pencitraan Ultrasonografi Organ Hepatobiliari pada Ular Sanca
}

\author{
Nurul Aeni Ayu Lestari ${ }^{1}$, Amira Putri Pertiwi ${ }^{1}$, Muhammad Piter Kombo ${ }^{2}$, \\ Ligaya ITA Tumbelaka ${ }^{3} \dagger$, Mokhamad Fakhrul Ulum ${ }^{3} *$ \\ ${ }^{1}$ Program Sarjana Fakultas Kedokteran Hewan, Institut Pertanian Bogor \\ ${ }^{2}$ Taman Reptil, Taman Mini Indonesia Indah (TMII) Jakarta \\ ${ }^{3}$ Departemen Klinik, Reproduksi dan Patologi, Fakultas Kedokteran Hewan, Institut Pertanian Bogor
}

ABSTRAK: Teknologi pencitraan ultrasonografi memiliki peranan penting dalam manajemen kesehatan pada ularsanca. Struktur sistem organ di dalam tubuh seperti hepatobiliari dapat dipantau secara non-invasif menggunakan teknologi ultrasonografi. Citraultrasonografi organ hepatobiliari pada tiga spesies ular sanca, yang terdiri atas sanca batik, sanca bodo, dan sanca bola dilaporkan dalam tulisan ini. Pencitraan organ hepatobiliari dilakukan menggunakan trasnduser linear dengan frekuensi $10 \mathrm{MHz}$. Ukuran organ hepatobiliari diukur berdasarkan nomor dan jumlah sisik ventral tubuh. Hasil pengukuran menunjukkan bahwa organ hati pada ketiga sanca memiliki ukuran yang bervariasi dan berada diantara persinggungan nomor sisik ventral 72-102. Organ kelenjar empedu berukuran 7-9 sisik dan berada di antara nomor sisik ventral yang bervariasi. Derajat ekogenitas organ hepatobiliari di antara ketiga sanca tidak menunjukkan adanya perbedaan. Ekogenisitas organ hati pada ketiga sanca tampak hipoekoik dengan dinding hiperekoik di antara bayangan organ paru-paru yang tampak hiperekoik. Kelenjar empedu tampak anekoik dengan dinding hiperekoik berada diantara organ limpa yang tampak hiperekoik dan organ pankreas yang tampak hipoekoik.

Kata kunci:

hepatobiliari, sisik ventral, ultrasonografi, ular sanca.

\section{- PENDAHULUAN}

Dewasa ini ular telah dimanfaatkan tidak hanya sebagai sumber bahan baku kerajinan kulit tetapi telah telah dimanfaatkan sebagai hewan peliharaan. Informasi manajemen kesehatan dan teknik diagnostik yang tepat menjadi penting untuk dikembangkan dalam rangka menunjang budidaya ular. Ultrasonografi merupakan suatu teknik diagnostik non-invasif pada ular (Stahlschmidt et al. 2011) yang dapat dilakukan secara cepat, aman, dan efisien (Gnudi et al. 2009). Organ hepatobiliari tersusun atas hati dan kelenjar empedu yang berfungsi untuk membuang produk sisa dari hati menuju ke duodenum dan membantu proses pencernaan lemak dengan pelepasan empedu (Boyer 2013). Status kesehatan organ hepatobiliari dapat dipantau secara ultrasonografi untuk mengevaluasi struktur parenkima hati, penegakkan diagnosis ikterus, kolesistitis, massa kista dan padatan, serta penyakit fokal dan difusa hati lainnya (Konde dan Pugh 1996).

\section{- BAHAN DAN METODE}

Ular sanca sebanyak 3 ekor terdiri dari 3 spesies berbeda, yaitu sanca batik (Malayopython reticulatus), sanca bodo (Python molurus bivittatus), dan sanca bola (Python regius). Ular sanca berasal dari Taman Reptil Taman Mini
Indonesia Indah dan para penghobi ular di sekitar kampus Institut Pertanian Bogor (IPB).

Orientasi pencitraan untuk pengukuran dan penentuan posisi organ hepatobiliari dilakukan menurut jumlah dan nomor sisik ventral tubuh. Menurut Banzato et al. (2012), posisi organ hati berada pada dua pertiga panjang tubuh, sedangkan kelenjar empedu tepat berada di belakang organ hati. Organ hepatobiliari dicitrakan menggunakan ultrasonografi mode brightness (SonoDop S-3X, PT Karindo Alkestron, Indonesia) dengan transduser linear. Transduser jenis linear berfrekuensi $10 \mathrm{MHz}$. Standar pandang yang digunakan adalah longitudinal dan transversal terhadap sumbu tubuh. Ular ditangani dan dikekang secara fisik tanpa menggunakan sedasi atau bius dalam bak berisi air. Air digunakan sebagai pengganti gel ultrasound untuk mempermudah pengambilan gambar.

\section{- HASIL DAN PEMBAHASAN}

Ukuran organ hati berdasarkan jumlah sisik ventral ketiga sanca adalah bervariasi dengan posisi organ berada pada

\footnotetext{
Diterima : 28 Juli 2017

Direvisi : 14 Agustus 2017

Disetujui : 16 Agustus 2017
} 
singgungan nomor sisik ventral 72-102. Sedangkan ukuran kelenjar empedu berdasarkan jumlah sisik ventral ketiga sanca adalah 7-9 sisik dengan posisi organ berada di tengah panjang tubuh pada rentang nomor sisik ventral yang bervariasi (Tabel 1).

Tabel 1 Ukuran dan posisi organ hepatobiliari ular sanca berdasarkan jumlah dan nomor sisik ventral (tanda kurung)

\begin{tabular}{|cccc|}
\hline Organ & $\begin{array}{c}\text { Sanca Batik } \\
\text { (Malayopython } \\
\text { reticulatus })\end{array}$ & $\begin{array}{c}\text { Sanca Bodo } \\
\text { (Python molurus } \\
\text { bivittatus) }\end{array}$ & $\begin{array}{c}\text { Sanca Bola } \\
\text { (Python } \\
\text { regius })\end{array}$ \\
\hline Hati & $60(72-132)$ & $46(70-116)$ & $35(67-102)$ \\
$\begin{array}{c}\text { Kantung } \\
\text { empedu }\end{array}$ & $9(178-187)$ & $9(148-157)$ & $7(116-123)$ \\
\hline
\end{tabular}

Hati terletak di belakang jantung, memiliki bentuk memanjang pada dua pertiga tubuh dan berada di medial dari organ paru-paru kanan dan kiri. Hati memiliki ekogenisitas yang lebih hipoekoik dengan dinding yang hiperekoik (Banzato et al. 2012). Citra organ paru-paru yang berisi udara terlihat adanya bayangan hiperekoik di sekitar hati (Gambar 1).

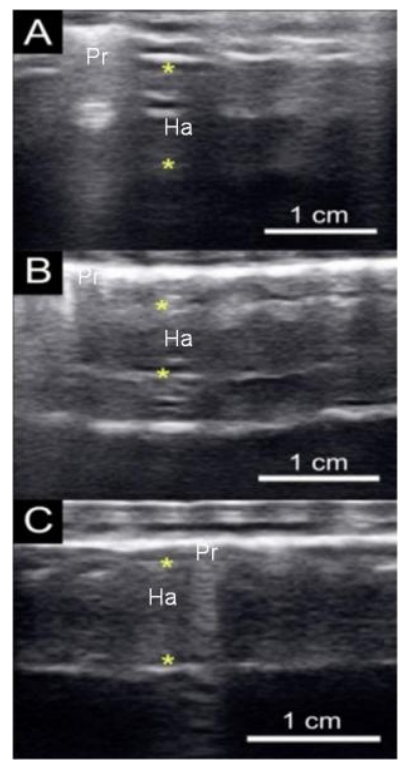

Gambar 1 Sonogram organ hati ular sanca batik (A), sanca bodo (B), dan sanca bola (C) pada standar pandang longitudinal. Keterangan: batas organ $(*)$, paru-paru $(\operatorname{Pr})$ dan hati (Ha).

Citra ultrasonografi kelenjar empedu tampak berbentuk oval hingga membulat, memenuhi hampir seluruh rongga tubuh, dan terpisah dari organ hati (Gambar 2). Kelenjar empedu terpisah dari organ hati dan berlokasi di ventrolateral dari lambung, limpa, dan pankreas (Banzato $e t$ al. 2012). Kelenjar empedu memiliki ekogenisitas yang tampak anekoik dengan dinding hiperekoik. Menurut Isaza et al. (1993), kelenjar empedu berbentuk oval, memiliki struktur anekoik dengan dinding yang hiperekoik.
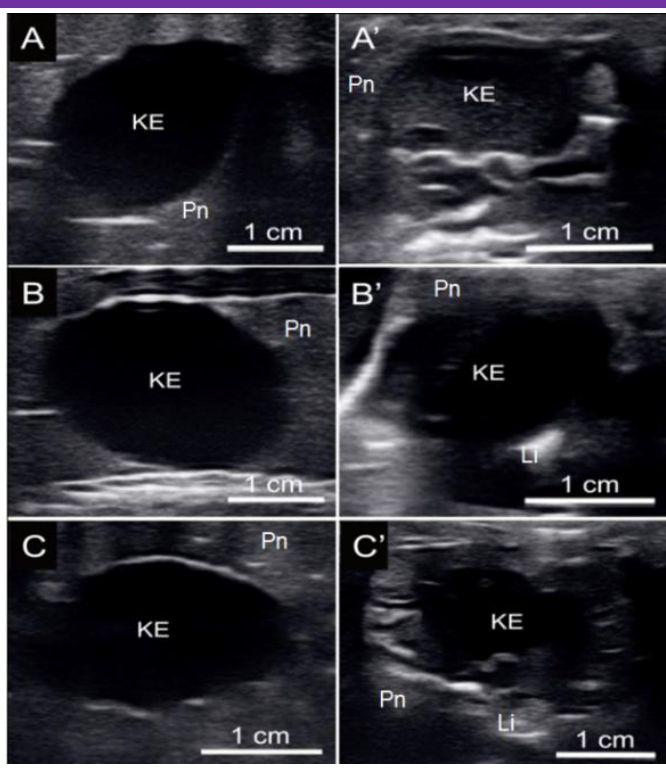

Gambar 2 Sonogram kelenjar empedu (KE) secara longitudinal pada ular sanca batik (A), sanca bodo (B), sanca bola (C) dan secara transversal pada ular sanca batik (A'), sanca bodo (B'), dan sanca bola (C'). Keterangan: pankreas (Pn) dan limpa (Li).

\section{- SIMPULAN}

Pencitraan ultrasonografi organ hepatobiliari pada ular sancadapat dilakukan dengan mudah tanpa pembiusan. Ekogenitas organ hati tampak hipoekoik sedangkan kantung empedu anekoik dengan ukuran dan posisi organ ditentukan berdasarkan jumlah dan nomor sisik ventral.

\section{- INFORMASI PENULIS}

Penulis untuk Korespondensi

*MFU: ulum@ipb.ac.id, †LIT: ligaya290212@gmail.com

\section{n UCAPAN TERIMA KASIH}

Terima kasih kepada PT Karindo Alkesteron yang menyediakan alat ultrasonografi dalam penelitian ini.

\section{- PUSTAKA ACUAN}

Banzato T, Russo E, Finotti L, Milan M, Gianesella M, Zotti A. 2012. Ultrasonographic anatomy of the coelomic organs of boid snakes. Am. J. Vet. Res. 73(5) 634-645.

Boyer JL. 2013. Bile formation and secretion. Compr. Physiol. 3(3): 1035-1078.

Gnudi G, Volta A, Ianni F, Bonazzi M, Manfredi S, Bertoni G. 2009. Use of ultrasonography and contrast radiography for snake gender determination. Vet. Radiol. Ultrasound. 50(3): 309-311.

Isaza R, Ackerman N, Jacobson ER. 1993. Ultrasound imaging of the coelomic structures in the Boa constrictor (Boa constrictor). Vet. Radiol. 34(6): 445-450.

Stahlschmidt Z, Brashears J, DeNardo D. 2011. The use of ultrasonography to assess reproductive investment and output in pythons. Biol. J. Linn. Soc. 103: 772-778.

Konde LJ, Pugh CR. 1996. Radiology and sonography of the digestive system. Dalam: Handbook of Small animal Gastroenterology. TR Tams, Ed. Philadelphia (US): Saunders. 